\title{
Effect of selected flavonoids on the behavior of the bird cherry-oat aphid (Rhopalosiphum padi L.) during the colonization of winter wheat
}

\author{
Wpływ wybranych flawonoidów na zachowanie \\ mszycy czeremchowo-zbożowej (Rhopalosiphum padi L.) \\ podczas zasiedlania pszenicy ozimej
}

\author{
Agnieszka Kozak*, Grzegorz Chrzanowski, Cezary Sempruch, Agnieszka Klewek, Marta Chwedczuk
}

\section{Summary}

The aim of the study was to determine the effects of such flavonoids as: apigenin, luteolin, quercetin, mirycetin, $(+)$-catechin and (-)-epicatechin on the behavior of wingless females and larvae of bird cherry-oat aphid (Rhopalosiphum padi L.) during the colonization of winter wheat seedlings. All the tested compounds showed deterrence activity against thebird cherry-oat aphid morphs. Significant differences in influence of tested flawonoids on behavior of wingless females and larvae were observed. Generally, wingless females were more susceptible than larvae. (-)-Epicatechin and quercetin were the most effective in relation to the wingless females and apigenin and (+)-catechin strongest modified larvae colonization behavior.

Key words: flavonoids; deterrents; biopesticides; aphids; winter wheat

\section{Streszczenie}

Celem badań było określenie wpływu flawonoidów: apigeniny, luteoliny, kwercetyny, mirycetyny, (+)-katechiny i (-)-epikatechiny na zachowanie bezskrzydłych samic i larw mszycy czeremchowo-zbożowej (Rhopalosiphum padi L.) podczas zasied-lania siewek pszenicy ozimej. Stwierdzono, iż wszystkie testowane flawonoidy charakteryzowały się deterentną aktywnością w stosunku do tych stadiów rozwojowych mszycy czeremchowo-zbożowej. Większą wrażliwością na badane związki odznaczały się bezskrzydłe samice niż larwy. W stosunku do samic najsilniejszym deterentem okazała się (-)-epikatechina i kwercetyna, a w stosunku do larw apigenina i (+)-katechina.

Słowa kluczowe: flawonoidy; deterenty; biopestycydy; mszyca czeremchowo-zbożowa; pszenica ozima

\author{
Uniwersytet Przyrodniczo-Humanistyczny w Siedlcach \\ Katedra Biochemii i Biologii Molekularnej \\ Prusa 12, 08-110 Siedlce \\ *corresponding author: agnieszka_kozak2@o2.pl
}




\section{Wstęp / Introduction}

Mszyca czeremchowo-zbożowa (Rhopalosiphum padi L.) jest jednym z dominujących szkodników na uprawach zbożowych w Polsce. Formy anholocykliczne $R$. padi bezpośrednio przed żniwami przelatują na trawy i kukurydzę, a następnie zasiedlają zboża ozime po wschodach. Natomiast formy holocykliczne wracają na żywiciela pierwotnego, drzewa czeremchy zwyczajnej (Prunus padus L.) (Mrówczyński i Wachowiak 2009). Jesienią, podczas sprzyjających warunków, gatunek ten stwarza niebezpieczeństwo silnych infekcji wirusowych na oziminach, przenosząc wirusy żółtej karłowatości jęczmienia (BYDV) (Ruszkowska 2006).

W wyniku procesów koewolucji rośliny wykształciły szereg mechanizmów obronnych zabezpieczających je przed atakiem roślinożernych owadów, w tym zdolność do biosyntezy szerokiej gamy związków fenolowych, spośród których ważną rolę odgrywają flawonoidy (Kubo 2006). Niektóre $\mathrm{z}$ nich są zaangażowane $\mathrm{w}$ procesy rozpoznawania roślin żywicielskich przez owady, podczas gdy inne mogą hamować ich żerowanie działając m.in. jako deterenty pokarmowe (Diaz Napal i wsp. 2010). W praktyce rolniczej przykładem zastosowania związków fenolowych w zwalczaniu szkodników są izoflawonoidy zawierające w swojej strukturze rotenon. Związki te wykorzystane zostały w produkcji komercyjnych pestycydów zwalczających wiele gatunków owadów (Małolepsza i Urbanek 2000). Rotenon jest składnikiem około 680 organicznych insektycydów ogrodowych. Z uwagi na swoje naturalne pochodzenie wydaje się być bezpieczniejszy niż syntetyczne pestycydy, gdyż w przeciwieństwie do nich ulega naturalnemu rozkładowi w glebie oraz wodzie (Dobrowolska 2002). Rotenon jest obecnie jedynym flawonoidem stosowanym komercyjnie na szeroką skalę, dlatego badania nad innymi związkami z tej grupy mogą przysłużyć się do powstawania nowych biopreparatów.

Program integrowanej ochrony roślin zakłada wykorzystanie metod niechemicznych do ochrony roślin uprawnych przed agrofagami. Opracowanie integrowanych zasad ochrony pszenicy przed szkodnikami jest szczególnie ważne ze względu na znaczenie gospodarcze tego zboża, mnogość gatunków na nim żerujących oraz konieczność stosowania pestycydów, charakteryzujących się toksycznością w stosunku do ludzi i środowiska. Integrowana ochrona pszenicy przed szkodnikami, podobnie jak i innych roślin uprawnych, uwzględnia takie elementy, jak: odpowiednia agrotechnika, stasowanie odmian odpornych czy biologiczne zwalczanie szkodników (Korbas i wsp. 2008). Ważne jest poszukiwanie naturalnych substancji czynnych biologicznie, takich jak wtórne metabolity roślinne, które biorą udział $\mathrm{w}$ mechanizmach obronnych roślin przed szkodnikami, a zatem mogłyby posłużyć do produkcji biopestycydów. Ważną grupą tych związków są flawonoidy, które wykazują antyżywieniową aktywność w stosunku do owadów, zakłócając fizjologiczne procesy zachodzące w ich organizmach (Cox 2004), mogąc pełnić rolę naturalnych biopestycydów.

W źródłach literaturowych jest niewiele danych dotyczących oddziaływania flawonoidów na zachowanie mszyc. Praca miała na celu określenie wpływu niektórych z tych związków na zachowanie mszycy czeremchowozbożowej podczas zasiedlania pszenicy zwyczajnej (Triticum aestivum L.).

\section{Materiały i metody / Materials and methods}

Do doświadczeń wykorzystano bezskrzydłe samice oraz larwy mszycy czeremchowo-zbożowej oraz siedmiodniowe siewki pszenicy ozimej odmiany Tonacja (nasiona pochodziły z Hodowli Roślin Strzelce). Hodowlę zarówno mszyc, jak i roślin prowadzono w warunkach kontrolowanych (temperatura $24^{\circ} \mathrm{C}$ w dzień i $18^{\circ} \mathrm{C}$ w nocy, wilgotność względna 70 $\pm 5 \%$ i fotoperiod 16L:8D), w pokoju hodowlanym Katedry Biochemii i Biologii Molekularnej Uniwersytetu Przyrodniczo-Humanistycznego w Siedlcach.

Do testów zastosowano $1 \mu \mathrm{M}$ i $1 \mathrm{mM}$ stężenia następujących flawonoidów: apigeniny, luteoliny, kwercetyny, mirycetyny, (+)-katechiny i (-)-epikatechiny (Sigma Chemical Co., St. Louis, Mo USA). Ich wpływ na zachowanie się bezskrzydłych samic i larw R.padi podczas zasiedlania siewek pszenicy badano w warunkach kontrolowanych zgodnie z metodą Powell i wsp. (1997). Liście siedmiodniowych siewek pszenicy zanurzano w metanolowych roztworach badanych substancji lub w wodzie redestylowanej (siewki kontrolne) na 20 s. Następnie umieszczono je na brzegach szalki Petriego (o średnicy $18 \mathrm{~cm}$ ) wyścielonej bibułą filtracyjną, nasączoną wodą. $\mathrm{Na}$ jednej szalce umieszczano po trzy siewki potraktowane każdym ze stężeń badanego związku oraz siewki kontrolne, przy czym każdy z flawonoidów testowany był na oddzielnej szalce. Na środkową część szalki nanoszono po 20 bezskrzydłych samic lub larw $R$. padi. Szalki zamykano, a po upływie 15, 30, 60 i 90 min liczono mszyce na poszczególnych siewkach. Doświadczenie wykonano w pięciu powtórzeniach dla każdego z badanych związków zarówno dla samic, jak i larw. Na podstawie otrzymanych wyników obliczono względny indeks deterencji (I), według poniższego wzoru:

$$
\mathrm{I}=\frac{(\mathrm{C}-\mathrm{T})}{(\mathrm{C}+\mathrm{T})}
$$

C - liczba mszyc na siewkach kontrolnych,

$\mathrm{T}$ - liczba mszyc na siewkach zanurzonych w roztworach badanych metabolitów wtórnych.

Otrzymane wyniki poddano jednoczynnikowej analizie wariancji (ANOVA). Istotność różnic między średnimi wartościami względnego indeksu deterencji szacowano z wykorzystaniem testu wielokrotnego rozstępu Duncana przy poziomie istotności $\mathrm{p} \leq 0,05$.

\section{Wyniki i dyskusja / Results and discussion}

Próbę określenia wpływu flawonoidów na zachowanie się $R$. padi podczas zasiedlania siewek pszenicy podjęto w oparciu o względny indeks deterencji. Współczynnik ten osiąga wartości od -1 do 1 , przy czym ujemne wskazują, iż badany związek jest atraktantem, zero, że nie wykazuje aktywności, a dodatnie, że jest deterentem. Otrzymane 
wyniki wykazały, że wszystkie testowane związki były deterentami w stosunku do mszycy czeremchowozbożowej. Wyższą wrażliwością odznaczały się bezskrzydłe samice niż larwy. W przypadku samic względne indeksy deterencji (I) dla 1,0 mM roztworów (-)-epikatechiny i kwercetyny przyjmowały najwyższe wartości $(\mathrm{I}=0,80-0,98)$ spośród wszystkich testowanych flawonoidów przy czym (-)-epikatechina charakteryzowała się najsilniejszym działaniem deterentnym. Najsłabiej oddziaływała na bezskrzydłe samice $(+)$-katechina w niższym z zastosowanych stężeń $(I=0,13-0,17)$ przez pierwsze $30 \mathrm{~min}$ trwania eksperymentu. Ponadto dla apigeniny i mirycetyny nie stwierdzono istotnych statystycznie różnic w sile oddziaływania deterentnego zastosowanych stężeń. Natomiast między różnymi stężeniami (+)-katechiny i (-)-epikatechiny wykazano potwierdzone statystycznie różnice utrzymujące się przez cały czas trwania doświadczenia (rys. 1).

Stwierdzono również, że zastosowane stężenia testowanych flawonoidów w różnym stopniu oddziaływały na zasiedlanie siewek pszenicy przez larwy $R$. padi. Najsilniejszym oddziaływaniem deterentnym w stosunku do tego stadium rozwojowego charakteryzowała się $(+)$-katechina w stężeniu $1 \mathrm{mM}$ (I = 0,90 po $30 \mathrm{~min}$ trwania obserwacji) oraz apigenina i mirycetyna. Najsłabiej na larwy wpływała luteolina $\mathrm{w}$ obu zastosowanych stężeniach. W przypadku larw między wartościami względnego indeksu deterencji wyliczonego dla badanych stężeń wszystkich objętych doświadczeniami flawonoidów stwierdzono istotne różnice statystyczne. Roztwory 1,0 $\mu \mathrm{M}$ oddziaływały w większości przypadków istotnie słabiej niż 1,0 mM, co świadczy o zmniejszającej się wrażliwości larw na testowane związki wraz ze spadkiem ich stężenia (rys. 2).

Wcześniejsze badania dowiodły, że roślinne flawonoidy u owadów mogą łączyć się $\mathrm{z}$ receptorem hormonu ekdyzonu, powodując zmiany $w$ ich zachowaniach żywieniowych, co w konsekwencji prowadzi do zwiększania śmiertelności przez redukcję rozwoju i płodności (Ruuhola i wsp. 2001). Stwierdzono, iż flawonoidy wyizolowane z Eucalyptus saligna były deterentami pokarmowymi dla światłówki naziemnicy (Spodoptera exigua Hübner) i szarańczy wędrownej (Locusta migratoria L.) (Simmonds 2003). Ustalono również, iż genisteina hamowała żerowanie chrząszcza Costelytra zealandica (Harborne i Williams 2000). Inne badania wykazały, że luteolina i genisteina zniechęcały do żerowania mszycę grochowiankę (Acyrthosiphon pisum Harris) (Goławska i Łukasik 2012). Wu i Guo (2001) podają, że galokatechina, rutyna i izokwercetyna oddziaływały toksycznie na słonecznicę orężówkę (Helicoverpa armigera Hüb.), której

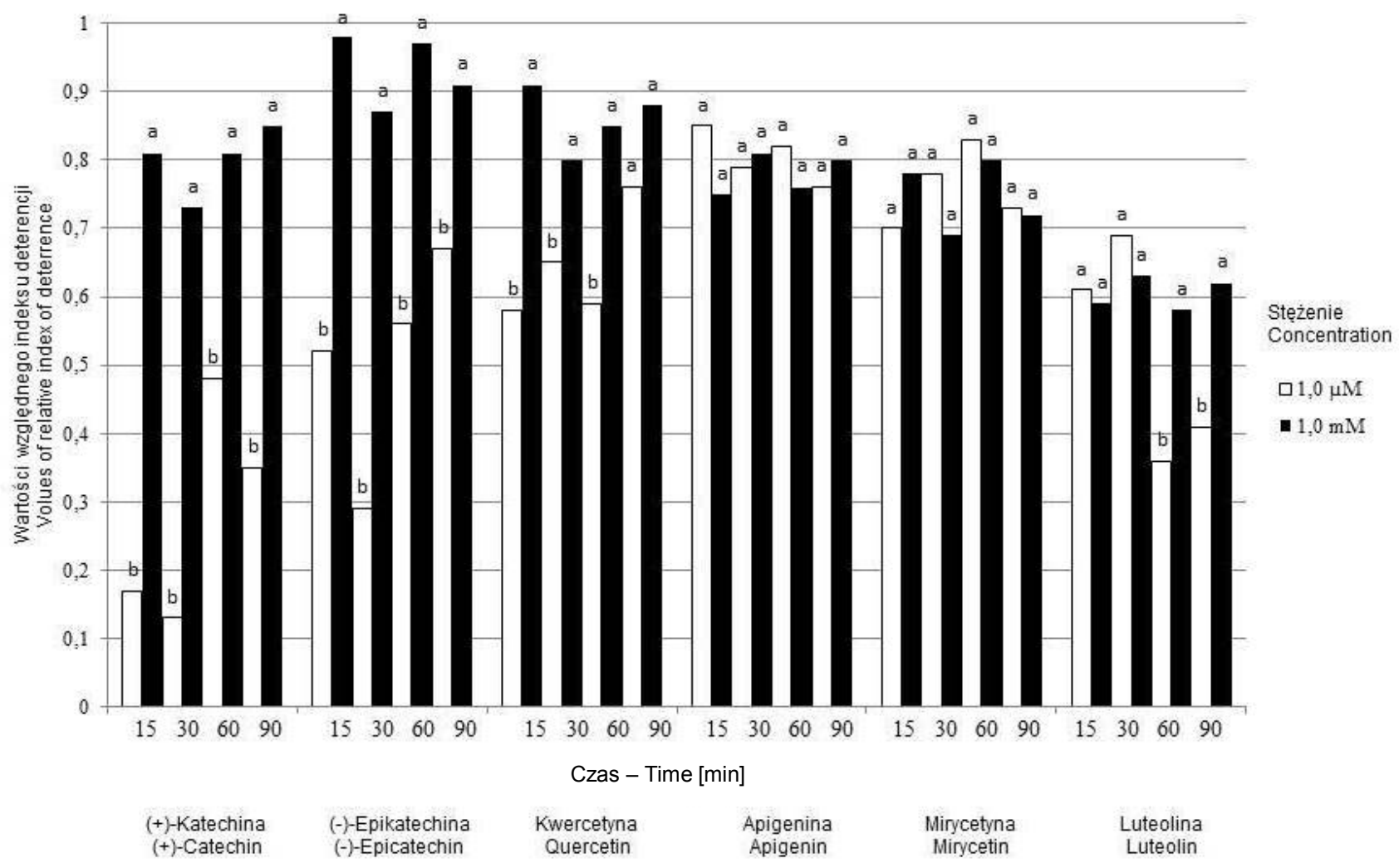

Flawonoid - Flavonoid

Wartości oznaczone innymi literami różnia się statystycznie przy $p \leq 0,05$ (test Duncana)

Values marked with different letters differ statistically at $p \leq 0.05$ (Duncan's test)

Rys. 1. Wartości względnego indeksu deterencji roztworów badanych flawonoidów w stosunku do bezskrzydłych samic $R$. padi

Fig. 1. Values of relative index of deterrence solutions of analyzed flavonoids in relation to $R$. padi apterous females 


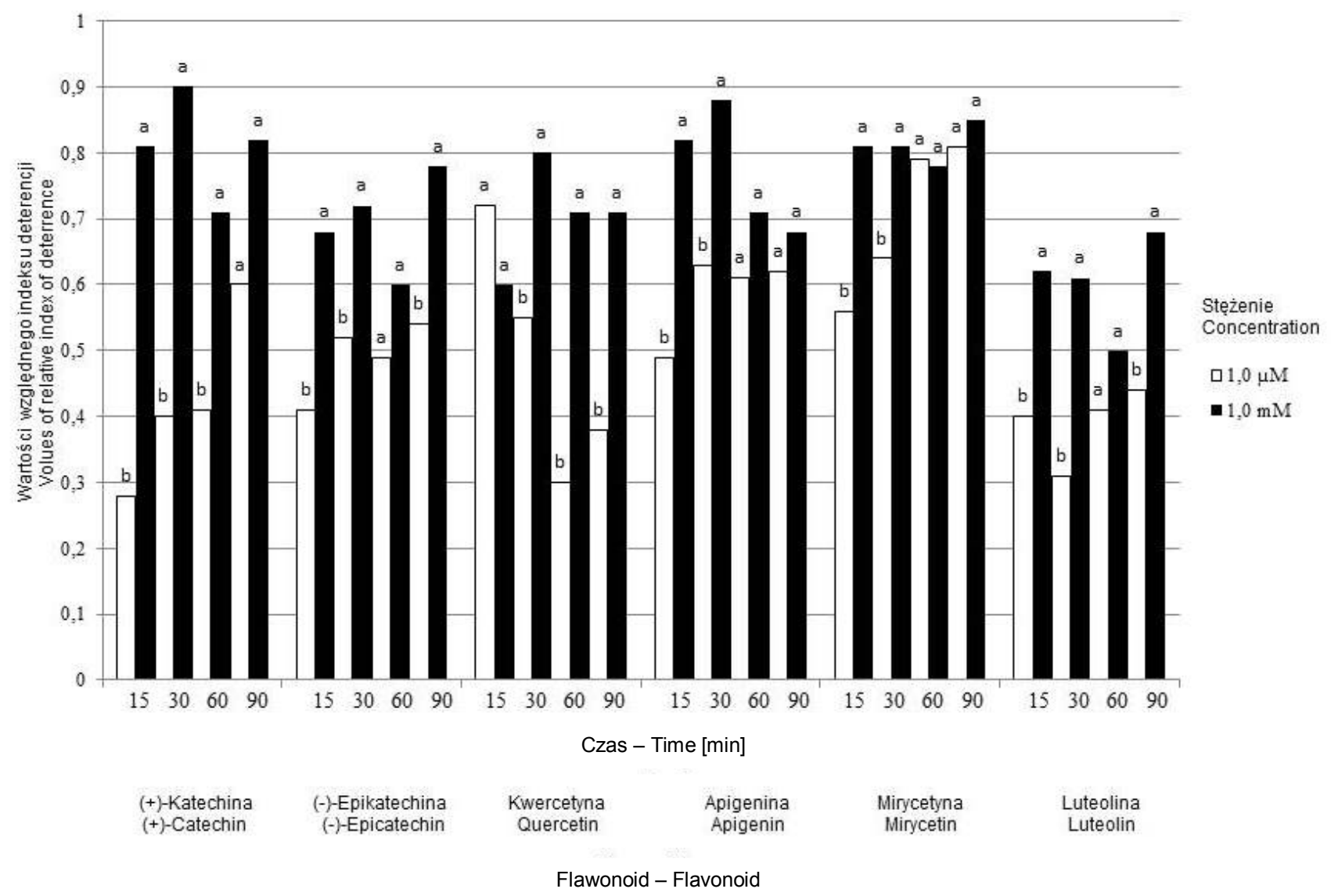

Wartości oznaczone innymi literami różnią się statystycznie przy $p \leq 0,05$ (test Duncana)

Values marked with different letters differ statistically at $p \leq 0.05$ (Duncan's test)

Rys. 2. Wartości względnego indeksu deterencji roztworów badanych flawonoidów w stosunku do larw R. padi

Fig. 2. Values of relative index of deterrence solutions of analyzed flavonoids in relation to larvae $R$. padi

gąsienice żerują na bawełnie i innych ważnych gospodarczo gatunkach roślin. Pinocembryna powodowała przewlekłe zatrucie larw Epilachna paenulata Germar (Diaz Napal i wsp. 2010). Kwercetyna nadawała odporność dzikim gatunkom roślin z rodzaju Vigna, odstraszając mszyce złotokapowo-wykową (Aphis craccivora Koch.) (Lattazio i wsp. 2006) oraz hamowała aktywność ATP-azy mitochondrialnej i oksydoreduktaz, powodując zaburzenia w rozwoju larw słonecznicy amerykańskiej (Helicoverpa zea Boddie) (Simmonds 2001). Stwierdzono, że szczególnie wysoką aktywnością biologiczną odznaczały się aglikony flawonoidów, zmniejszały one tempo wzrostu i wydłużały okres trwania pierwszego stadium larwalnego motyla paśnika jesieniaka (Epirrita autumnata Borkhausen) (Lahtinen i wsp. 2004).

Różnica we wrażliwości na badane związki poszczególnych morf owadów może wynikać ze specyficznych przystosowań wynikających z roli, jakie stadia te spełniaja w cyklu rozwojowym danego gatunku.

\section{Wnioski / Conclusions}

1. Wszystkie badane flawonoidy charakteryzowały się deterentną aktywnością w stosunku do badanych stadiów rozwojowych mszycy czeremchowo-zbożowej, często nie dopuszczając do zbliżenia się mszyc do siewek pszenicy, tym samym uniemożliwiały rozpoczęcie żerowania.

2. Bardziej wrażliwe na zastosowane flawonoidy już w niskim stężeniu okazały się bezskrzydłe samice R. padi.

3. Testowane flawonoidy mogą posłużyć do produkcji biopreparatów przeciwko mszycy $R$. padi.

\section{Literatura / References}

Cox P.D. 2004. Potential for using semiochemicals to protect stored products from insect infestation. Journal of Stored Products Research 40: 1-25.

Diaz Napal G.N., Defagó M.T., Valladares G.R., Palacios S.M. 2010. Response of Epilachna paenulata to two flavonoids, Pinocembrin and Quercetin, in a comparative study. Journal of Chemical Ecology 36: 898-904.

Dobrowolska A. 2002. Odmiany roślin transgenicznych Bt a pestycydy - aspekty środowiskowe i zdrowotne. Kosmos 51 (1): $99-104$. 
Goławska S., Łukasik I. 2012. Antifeedant activity of luteolin and genistein against the pea aphid Acyrthosiphon pisum. Journal of Pest Science 85: 443-450.

Harborne J.B., Williams Ch.A. 2000. Advances in flavonoid research since 1992. Phytochemistry 55: 481-504.

Korbas M., Mrówczyński M., Paradowski A., Horoszkiewicz-Janka J., Jajor E., Pruszyński G. 2008. Ochrona roślin w integrowanej produkcji pszenicy. [Plant protection in integrated production of wheat]. Progress in Plant Protection/Postępy w Ochronie Roślin 48 (4): 1502-1515.

Kubo I. 2006. New concept to search for alternate insect control agents from plants. p. 61-80. In: "Naturally Occurring Bioactive

Compounds 3" (M. Rai, M. Carpinella, eds.). Elsevier, Amsterdam, 826 pp.

Lahtinen M., Salminen J.-P., Kapari L., Lempa K., Ossipov V., Sinkkonen J., Valkama E., Haukioja E., Pihlaja K. 2004. Defensive effect surface flavonoid aglycones of Betulapubescens leaves against first instar Epirrita autumnata larvae. Journal of Chemical Ecology 30: 2257-2268.

Lattanzio V., Lattanzio V.M.T., Cardinali A. 2006. Role of phenolics in the resistance mechanisms of plants against fungal pathogens and insects. Phytochemistry: Advances in Resarch 37/661 (2): 23-67.

Małolepsza U., Urbanek H. 2000. Flawonoidy roślinne jako związki biochemicznie czynne. Wiadomości Botaniczne 44 (3/4): $27-37$.

Mrówczyński M., Wachowiak H. 2009. Mszyce - szkodniki zbóż. Wiadomości Rolnicze Polska 58 (6), s. 6.

Powell G., Hardie J., Pickett J.A. 1997. Laboratory evaluation of antifeedant compounds for inhibiting settling by cereal aphids. Entomologia Exprimentalis et Applicata 84: 189-193.

Ruszkowska M. 2006. Uwarunkowania klimatyczne w rozprzestrzenianiu najważniejszych wektorów chorób wirusowych na zbożach w badanych regionach Polski. [Permanent and cyclic parthenogenesis of Rhopalosiphum padi (L.) (Homoptera: Aphidoidea) across different climate regions in Poland]. Progress in Plant Protection/Postępy w Ochronie Roślin 46 (1): 276-283.

Ruuhola T., Tikkanen O., Tahvanainen J. 2001. Differences in host use efficiency of larvae of a generalist moth, Operophtera brumata on three chemically divergent Salix species. Journal of Chemical Ecology 27: 1595-1615.

Simmonds M.S.J. 2001. Importance of flavonoids in insect-plant interactions: feeding and oviposition. Phytochemistry 56: 245-252.

Simmonds M.S.J. 2003. Flavonoid-insect interactions: recent advances in our knowledge. Phytochemistry 64: 21-30.

Wu Y.Q., Guo Y.Y. 2001. Potential resistance of tannins-flavoniods in upland cotton against Helicoverpa armigera (Hübner). Acta Ecologia Sinica 24: 286-289. 